\title{
1918 and the Habsburg Monarchy as Reflected in Slovak Historiography*
}

\author{
Júlia Čížová \\ Institute of History of Slovak Academy of Sciences, 81499 Bratislava, Klemensova 19, Slovakia, \\ julia.cizova@savba.sk
}

\section{Roman Holec}

Faculty of Arts of Comenius University Bratislava, 81801 Bratislava, Gondova 2, Slovakia; Institute of History of Slovak Academy of Sciences, 81499 Bratislava, Klemensova 19, Slovakia, rh1918@yahoo.com

Received 6 June 2021 | Accepted 12 October 2021 | Published online 3 December 2021

\begin{abstract}
With regard to the "long" nineteenth-century history of the Habsburg monarchy, the new generation of post-1989 historians have strengthened research into social history, the history of previously unstudied social classes, the church, nobility, bourgeoisie, and environmental history, as well as the politics of memory.

The Czechoslovak centenary increased historians' interest in the year 1918 and the constitutional changes in the Central European region. It involved the culmination of previous revisitations of the World War I years, which also benefited from gaining a 100-year perspective. The Habsburg monarchy, whose agony and downfall accompanied the entire period of war (1914-1918), was not left behind because the year 1918 marked a significant milestone in Slovak history. Exceptional media attention and the completion of numerous research projects have recently helped make the final years of the monarchy and the related topics essential ones.

Remarkably, with regard to the demise of the monarchy, Slovak historiography has focused not on "great" and international history, but primarily on regional history and its elites; on the fates of "ordinary" people living on the periphery, on life stories, and socio-historical aspects. The recognition of regional events that occurred in the final months of the monarchy and the first months of the republic is the greatest contribution of recent historical research. Another contribution of the extensive research related to the year 1918 is a number of editions of sources compiled primarily from the resources of regional archives. The result of such partial approaches is the knowledge
\end{abstract}

The authors gratefully acknowledge the contribution of the Slovak Research and Development Agency in the form of the project APVV-20-0526 Political Socialization in the Territory of Slovakia during the Years 1848-1993. The paper is a publication output of the Scientific Grant Agency of the Slovak Republic VEGA grant 1/0139/21: Slovak Intellectual at the Crossroads between Tradition and Modernism. 
that the year 1918 did not represent the discontinuity that was formerly assumed. On the contrary, there is evidence of surprising continuity in the positions of professionals such as generals, officers, professors, judges, and even senior old regime officers within the new establishment. In recent years, Slovak historiography has also managed to produce several pieces of work concerned with historical memory in relation to the final years of the monarchy.

Keywords: Slovak historiography after 1989, Habsburg Monarchy in historical memory, continuities and discontinuities, social and regional history

The year 1918 marked a significant milestone in Slovak history. From the ruins of the Habsburg monarchy, Czechoslovakia emerged. This ensured favorable conditions for the development of all that was being denied to Slovaks within Hungaryi.e. a national identity, language, educational system, culture, political institutions and mechanisms. Simultaneously, social structures, political structures and political culture became fully formed and ultimately gave birth to a modern nation. As Europe opened up, Slovak inhabitants had a chance to expand their horizons. They were able to absorb foreign cultural stimuli and fuse them with local traditions. The example of the more advanced Bohemia proved to be stimulating. For the first time in history, the territory of Slovakia had been designated-and has remained the same until now, apart from some minor changes. After 1918, the Slovaks became actors in the formation of their own state, which had a profound effect on their lives.

\section{The Monarchy and the Republic}

According to Tomáš G. Masaryk, the first president of Czechoslovakia, every state has to espouse a system of ideas if it is to justify its existence. František Palacký recognized the role of the Habsburg monarchy in providing a kind of a safeguard for small nations and in creating the conditions that would allow individual nations to develop equally. Nevertheless, in the century of nationalism, the monarchy failed to fulfil such an ambition. ${ }^{1}$

Instead, it proposed sovereign rule and the concept of dynasty as symbols of integration to its inhabitants, which factors were to play a defining role in unification. However, both symbols - sovereign and dynasty_-gradually assumed an air of hollowness and contemporaries started to question their significance. The symbols were too traditional and detached from reality to have a mobilizing effect on a broad spectrum of inhabitants of such an immense and varied empire. Additionally, they were too rational in circumstances that called for emotional values, which were encouraged by the respective nationalisms. With the onset of mass culture and politics, the former

1 Palacký, Idea státu rakouského. 
proved to be competitive environments and offered various alternative identities to the masses. Naturally, both national self-identification related to the modern understanding of the state as the product of a national community and the call for the democratization of politics had more success than the concept of an "Austrianism" that could not take on the ideology of nationalisms - the latter which, being dynamic and flexible phenomena, also managed to appropriate all the positive aspects of the empire.

On the one hand, the recognition and equal rights of the empire's nations were asserted; on the other, there were calls to abolish all differences. The monarchy thus found itself at odds with reality and it was the differences that the respective nationalisms highlighted. The dynasty and the sovereign as the unifying factors failed utterly in an era that shunned supranational symbols. ${ }^{2}$

The Czechoslovak Republic was based on the notions of humanism and democracy, the principles which were formulated by Masaryk himself in his work. Even though complex political and economic circumstances complicated the growth of the state in the interwar period, and there were instances of a democratic deficit, the contribution of the state to the development of a democratic political culture is undeniable. This fact is even more pronounced if we compare Czechoslovakia's political situation with that of neighboring countries, which were then home to autocratic and undemocratic regimes.

The 1918 constitutional changes brought about the dissolution of the multinational Habsburg state. In the ashes of the former monarchy, new states emerged and proclaimed themselves nation states. Czechoslovakia, too, distanced itself from the monarchy and viewed it as an archaic structure with numerous semi-feudal features. The republic's way of legitimizing itself was (also) to renounce the values and priorities of the former state, which were deemed "unworthy" of the twentieth century (Fig. 1-2).

\section{The issue of continuity}

On the other hand, republicanism, and, in many cases, the democratic system, were not impediments to the new elites. They adopted, cultivated, and expanded many features of the old monarchy. The mental legacy was too powerful-after all, the people were the same. This is why even in a strictly republican Czechoslovakia, the office of the first president shared many similarities with those of the former emperor (the myth and cult of the founder and "father" of the state, frugality, his uniform, his passion for horseback riding, the national birthday celebrations, his old age, charisma, and authority, etc.). To see discontinuity with the former state in the creation of Czechoslovakia is to perceive reality in simplified terms and to cultivate a myth. 


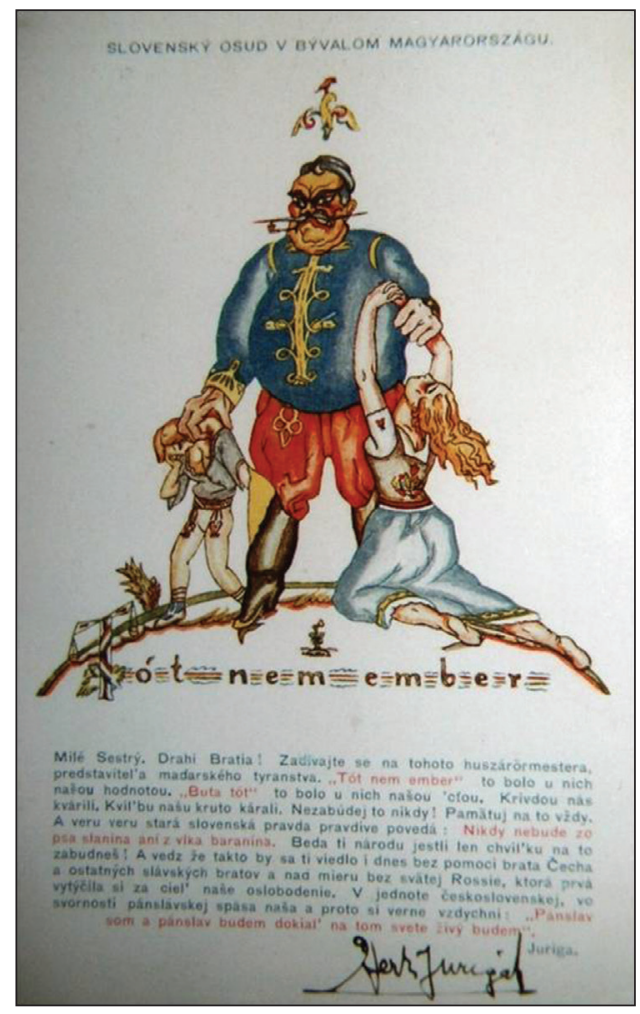

Figure 1 An allegory of Slovaks' suffering in Hungary (Literary Archive of the Slovak National Library in Martin)

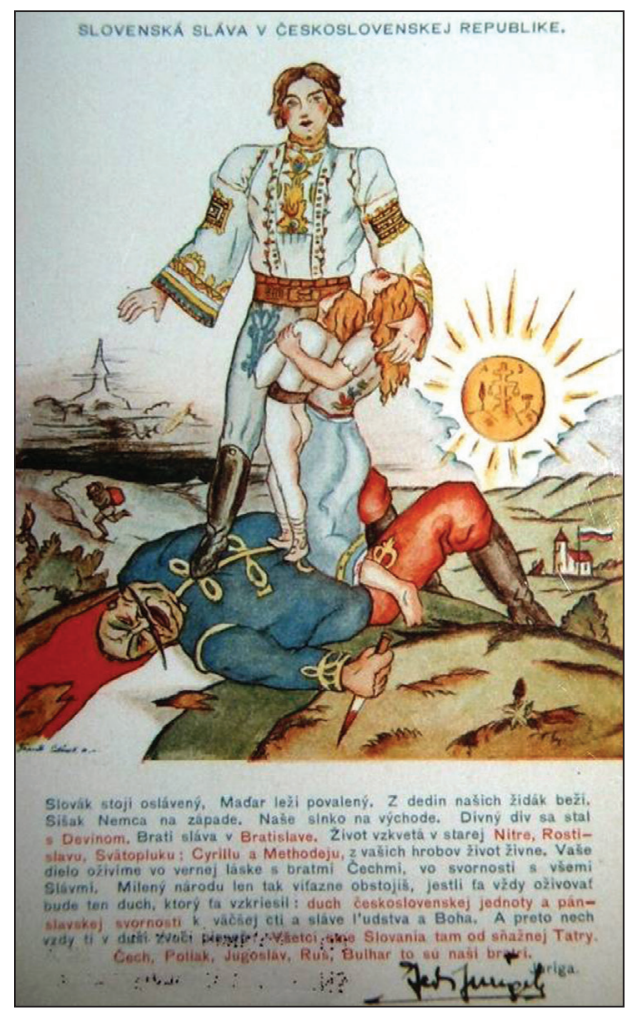

Figure 2 An allegory of Slovaks' happy lives in Czechoslovakia (Literary Archive of the Slovak National Library in Martin)

This may pose a paradox, but there is logic behind it. In spite of distancing itself from it, continuity with the monarchy was demonstrated in the form of unchanging rituals that gave new meaning to old symbols (the status and authority of the sovereign and the president, as mentioned earlier). Contemporary critics as well as the daily press noted such phenomena with embarrassment: "When lecturing about the president, teachers spoke the same way they used to do under the Kaiser. Progressives' lectures and articles about the head of the state reek of sycophancy and devotedness. Once again, they are just insincere empty words."3

Indeed, a recent theory claims that the successor state which most resembled the Habsburg monarchy vis-à-vis its structure (e.g. the ethnicity issue, and the elimination of major civilizational differences) and potential development (democratic, economic, and political) was not Austria, but Czechoslovakia. ${ }^{4}$

3 Republikánství a systém demokracie. Pražský večerník from 4. 8. 1923. As quoted in Pehr, "Deset let existence meziválečného Československa," 196.

4 Ther, "Druhý život habsburské monarchie v Československu," 121. 
The Czechoslovak centenary increased historians' interest in the year 1918 and the constitutional changes in the Central European region. This involved the culmination of the previous revisitations of the World War I years, which also benefited from gaining a100-year perspective. The Habsburg monarchy, whose agony and downfall accompanied the entire period of war (1914-1918) was not left behind. The exceptional media attention and the completion of numerous research projects have recently helped make the final years of the monarchy and the relating topics essential ones.

Remarkably, with regard to the demise of the monarchy, Slovak historiography has focused not on "great" and international history, but primarily on regional history and its elites; on the fates of "ordinary" people living on the periphery, on life stories, and socio-historical aspects. The recognition of regional events that occurred in the final months of the monarchy and the first months of the republic is the greatest contribution of recent historical research. ${ }^{5}$ The same approach is also used by Slovakia-based Hungarian historians who deal with minorities.

The outstanding synthetic approach of Gabriela Dudeková Kováčová focused on social history and Alltagsgeschichte of World War I. She observed the mechanisms of state propaganda, the regime's repressive measures and their effect on families and children. The new theoretical and interpretative approaches are implemented, or rather based, on brand new data. ${ }^{6}$ Economic history was contributed to by several key studies that related the stories of individual entrepreneurial elites. ${ }^{7}$

Another contribution made by the extensive research related to the year 1918 (the monarchy's final stage and the early months of the republic) is a number of editions of sources compiled primarily from the resources of regional archives. Indeed, they show firsthand that matters were often not perceived the same way as they were seen and interpreted in Prague. ${ }^{8}$

$5 \quad$ E.g. Furmaník, Spiš a vznik Československej republiky; Tokárová and Pavlovič, eds, Na ceste k slovenskej štátnosti, 11-239; Jarinkovič, Kárpáty and Dulovič, eds, Košice 1918-1938; Belej, Keresteš and Palárik, eds, Mílniky 20. storočia v regióne Nitrianskeho kraja. Likewise, see texts regarding the regions of Galanta, Šala and Dunajská Streda (V. Nováková), Púchov (P. Makyna), Kysuce, Orava and Spiš (P. Matula) and Košice (V. Kárpáty) in the collective monograph: Letz and Makyna, eds, Rok 1918 v historickej pamäti Slovenska. With regard to Hungarians on the future Slovak territory: Simon, Az elsö év kisebbségben; Simon, "Az 1918-19-es államfordulat első hetei”; Kerényi, “Gömör az 1919-es államfordulatok tükrében”; Simon, “Tri obsadenia Košíc. Paralely a poučenia.”

6 Dudeková Kováčová, Človek vo vojne. New interpretative approaches mainly from social history are implemented e.g., in Kováč, Kowalská and Šoltés, eds, Spoločnost' na Slovensku, Dudeková Kováčová, "Filantrop a sociálny politik"; Vörös, "Slovenský Walenrod," and Mannová, Minulost' ako supermarket?

7 Holec, Dinamitos történelem; Holec, Dejiny plné dynamitu; Gaučík, Podnik v osídlach štátu.

8 Bandolová et al., eds, Od Uhorského královstva k Československej republike; Bartal et al., eds, Začleňovanie Slovenska. 
The result of such partial approaches has been the re-affirmation of the knowledge that the year 1918 did not represent the discontinuity that was formerly assumed. ${ }^{9}$ On the contrary, there is evidence of surprising continuity in the positions of professionals such as generals, officers, professors, judges, and even old senior regime officers in the new establishment. There are many examples of Slovaks, Germans, and Hungarians changing their coats and having successful careers even within the framework of the new state. This was especially visible in the sphere of state administration.

Veronika Szeghy-Gayer examined the mayors of municipal towns and towns with an established council in Slovakia. She arrived at clear conclusions: Out of 39 mayors, only ten (26 percent) fled to the new Hungary, 27 stayed in Czechoslovakia, and data about the remaining two are missing. Out of the 27 mayors who stayed, 14 pledged allegiance to the new state (and another did likewise, but only later); seven mayors did not pledge allegiance but stayed politically active, and five did neither. Every single compelling life story of multiple identities bears testament to political pragmatism. ${ }^{10}$ Likewise, the results of Veronika Szeghy-Gayer's analysis reveal much greater continuity than one would expect. For example, take the case of the town of Bardejov: In December 1923, as many as 39 percent of the pre-1918 members of the town council remained among the elected. In general, a considerable degree of adaptability became a characteristic trait not only of Bardejov, but throughout the whole of Eastern Slovakia. ${ }^{11}$

In the Czech Republic too, the centenary became the impulse that prompted socio-historical analysis. Unlike in Slovakia, extensive volumes and research projects regarding lieux de mémoire were produced. Martin Klečacký analyzed the county governors in Bohemia: the surprising results show that 40 percent of the highest-ranking officers stayed in their office until 1920, and almost 30 percent were transferred due to organizational reasons, which might have been linked to promotion. ${ }^{12}$

This already emphasized continuity was also confirmed by the German historian Robert Luft, who illustrated how several Vienna Reichstag members were "transformed" into members of the new Czechoslovak parliament. ${ }^{13}$ Similarly,

9 From the point of view of the Slovak national program, see Kováč, "Rok 1918 - kontinuita a diskontinuita." The argumentation of its author is based on the knowledge that the year 1918 was a major milestone in Slovak history, with significant discontinuous elements, and that several major changes had their social and political roots in the pre-war period.

10 Szeghy-Gayer, "Meštanostovia na rázcestí," 346-47. Just as remarkable were the conclusions regarding the post-1918 changes perceived by the Hungarian intelligentsia in Prešov and Košice, as defined in the work of Szeghy-Gayer, Felvidékböl Szlovenszkó.

11 Szeghy-Gayer, “Államfordulat és az újrastrukturálódó helyi elit,” 1215-36 (especially 1233).

12 Klečacký, "Převzetí moci," 693-732 (especially 711-12).

13 Luft, Parlamentarische Führungsgruppen. 
aging Austrian officers proved to be qualified and indispensable, in stark contrast to legionary officers, who lacked both proper training and theoretical knowledge. As with military school graduates, the latter were slow to replace the old cadres. ${ }^{14}$ So, of what discontinuity do we speak? The state simply did not have enough professionals-it had to retain former ones, and only gradually replaced them.

\section{The attitude to monarchy - evolution, differences, characteristics}

The official attitude towards the former monarchy did not tolerate any reflection on the topic of continuity. The development of the Slovak relationship towards AustriaHungary in the "long" nineteenth century, as shaped by the official historical memory, followed a comparatively simple trajectory. Slovak historiography mirrored it all the way, from its humble beginnings to its institutional professionalization. Shortly after 1918, the Czech model was thoroughly adopted. The Czech public, politicians, and historians alike dissociated themselves from the monarchy, the Habsburg dynasty, and the Catholicism associated with it. They considered it to be the cause of all that was wrong with their past. Czechoslovakia was to be the atonement for all wrongdoings, starting from the Battle of White Mountain and the subsequent "Dark Ages" to the failed aspirations of the nineteenth-century National Revival. This was in line with the so-called 11 Beneš Memoranda, which were penned at the turn of 1918/1919 for the purposes of the Paris Peace Conference and which established a variety of constructs and stereotypes used in the creation of a common Czechoslovak past within and before the Habsburg monarchy. ${ }^{15}$

The singular position of Czechoslovaks in history and also within the Slavic family was emphasized as early as in the first memorandum. This was due to a certain uniqueness, which Beneš emphasized - the same way Polish, Romanian, and Yugoslav politicians highlighted the importance of "their nations." Even the Czech (not Czechoslovak) historians, politicians, and sociologists allegedly were not all that clear about the special character of Czechoslovak national history (which is in itself an artificial construct). In this case, the alleged uniqueness lay at the root of the philosophy of Czech history (Fig. 3).

"All great Czechs and Slovaks have fought for great, humane ideas all their lives and thus, this shows that Czechoslovaks have successfully resisted the Germans' (and Hungarians') brutal violence only through the strength of spirit and high moral principles." ${ }^{16}$

\footnotetext{
14 See Kalhous, Budování armády; Hofman, "Causa Rudolf Kalhous,” 190-96.

15 Raschhofer, ed., Die tschechoslowakischen Denkschriften.

16 Raschhofer, ed., Die tschechoslowakischen Denkschriften, 27 (Memorandum no. 1).
} 


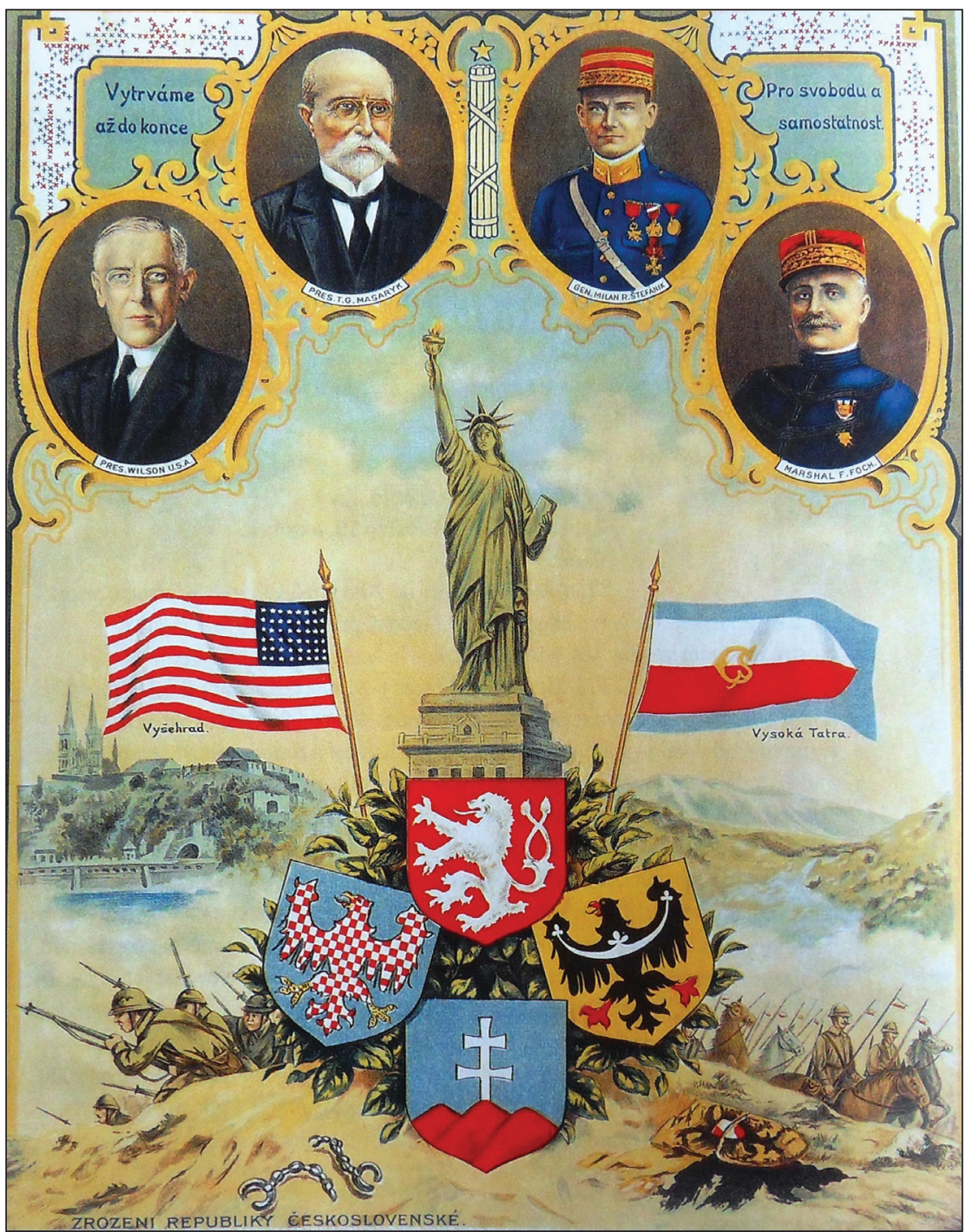

Figure $3 \mathrm{~A}$ poster celebrating the foundation of Czechoslovakia. It is rich with symbolic attributes (shackles and the Austrian eagle at the bottom, a clear identification with American values).

The alleged great historical role of Czechoslovaks lay in putting these principles into practice. The second, specifically Czech justification of the special role of Czechoslovaks was their great struggle against the Germans-their "hereditary enemies," who had almost exterminated them. Now, they were resurrected. Such rhetoric was, in a way, compulsory; a way of pandering to the French and thus scoring the necessary political points and sympathy. Both explanations can also be merged. In their unity, the civilizational mission of the Czechoslovaks can be epitomized. 
In other words, the emphasis was put on the fierce and irreconcilable struggle against the Germans as well as the feverish search for a moral, and, above all, new religious life, the latter being a result of the former. It is therefore hardly surprising that Bohemia was the cradle of great religious crises in Europe throughout history.

The Czechoslovaks also led the Slavic solidarity movement, and a memorandum refers to the words of the French Slavist and Sorbonne professor Louis Eisenmann. He spoke of the historical roots of this phenomenon, all the way from Dobrovský to Kollár:

"Kollár was a Slovak living in Budapest, the son of one of the most imperiled Slavic nations. He could clearly observe the growing threat posed by the Hungarian national movement. The threat clearly manifested itself in the $1848 / 9$ revolution..." 17

Hence, the source of small nations' unity, which also had a moral dimension. Hence also the strong philosophical justification of the idea of Slavic solidarity.

The Czech discourse, with its outright rejection and criticism of the Habsburg past, also made its mark on Slovak public opinion and the local educational system. Most of the history textbooks, were, after all, Czech or translated from Czech works. And yet, the Slovak elites had nothing (or very little) against the monarchy, even less against the dynasty, and nothing at all against Catholicism. There was a deeply rooted sense of loyalty towards the state and the dynasty among the Slovak political and intellectual elites. If there were objections, they were against Hungarians and the ethnic and political conditions in Hungary.

According to the official interpretation and official historical memory, the Czechoslovaks' history was one of struggles with German and Hungarian oppressors. The Germans and Hungarians were painted as egoistic, violent, and ambitious; the Czechoslovaks, on the other hand, were peace-loving, hard-working and temperate in all things. Czechoslovakia was introduced as the heir to Hussite traditions and the messenger of democratic and social values. The official interpretation claimed that the establishment of the republic saved Slovaks from extinction, and the central themes in scholarly circles became Hungarian ethnic policy and state-supported assimilationist efforts (Fig. 4). Hungary was thus perceived mainly through the prism of its ethnic practice. The state's endeavors in the sphere of industrial and agrarian development, transport infrastructure (95 percent of railway lines on the territory of present-day Slovakia were built before 1914) as well as culture and modernization in general faded into the background. When evaluating Slovak politics before 1918, the importance of Czech input was emphasized, as it was in the case of the internationalization of the issue of Slovaks in Europe (Robert William Seton-Watson, Björnstjerne Björnson, William Ritter, French bohemists).

17 Raschhofer, ed., Die tschechoslowakischen Denkschriften, 31 (Memorandum no. 1). 


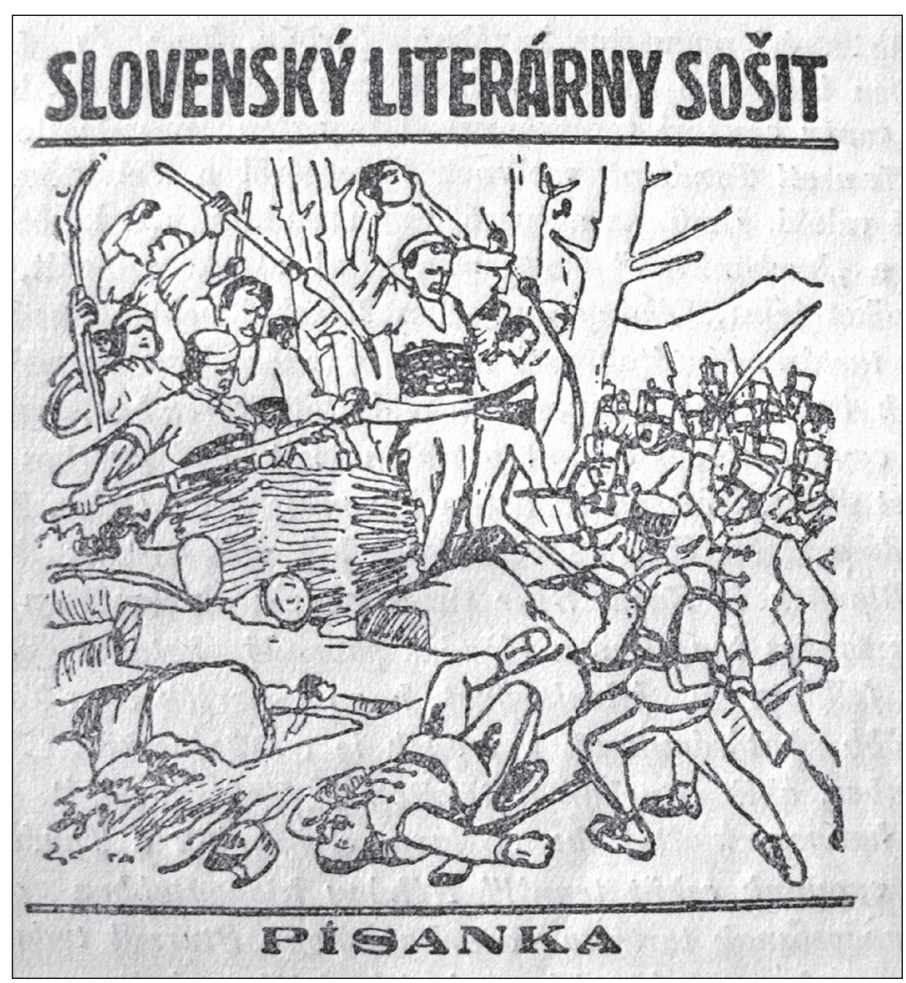

Figure 4 From the work of Pechány, Adolf, Mit tanítanak a felvidéki iskolákban? [What do they teach in Slovak schools?]. N. p. 1929, p. 15. This is a picture from a Slovak primary school workbook. Hungarian past was regarded as a life-and-death struggle.

There was no interest in mentioning the futility of Magyarization, nor of its short-sighted and counterproductive character. ${ }^{18}$ In light of this fact, it is impossible to explain why, had there been a referendum in 1918 (or shortly afterwards), the Slovaks would have likely voted to remain in the monarchy. That is why such public opinion was rather not discussed.

Official images of the harsh pre-1918 conditions which allegedly jeopardized the very existence of the Slovak nation were introduced into the school curriculum. Student populations who were being influenced in such a manner had no opportunity to compare their own empirical experience with the official historical memory. The images of hanged men lining the roadsides and gendarmes opening fire on defenseless crowds were meant to convince children that the new republic had brought salvation from the terrors of the past (Fig. 5). Similarly, the caricatures of an arrogant Hungarian landlord in periodicals and satirical magazines epitomized the

18 Rapant, K počiatkom madiarizácie; Rapant, Ilegálna madarizácia 1790-1840; Svetoň, Slováci v Madiarsku; Svetoň, Obyvatel'stvo Slovenska. 
former regime. On the state's tenth anniversary in 1928, many memorials, statues, and literary works were created in Slovakia. ${ }^{19}$ They revisited the pre-republic conditions in the spirit of the aforementioned rhetoric.

The political forces that criticized the republic's ethnic practice and certain Czech attitudes often declared that conditions in Hungary were in many ways more favorable. Such attitudes were a means of political and manipulative instrumentalization within the framework of political debates. During the period of the wartime Slovak Republic, both Czechoslovakia and the monarchy were subject to critical reappraisal. A logical continuation of Slovak National Revival efforts (linguistic until the end of the eighteenth century and political since the 1840s) was sought; one that would inevitably lead to the establishment of an independent state.

The restoration of Czechoslovakia and the rise of the Communists to power once again led to the cultivation of a positive attitude towards the common Czechoslovak state; however, this was projected in numerous reinterpretations in accordance with the new Marxist doctrine. The dynamic Marxist historiography followed the line of the critical stance towards the monarchy. The nineteenth-century Hungary and

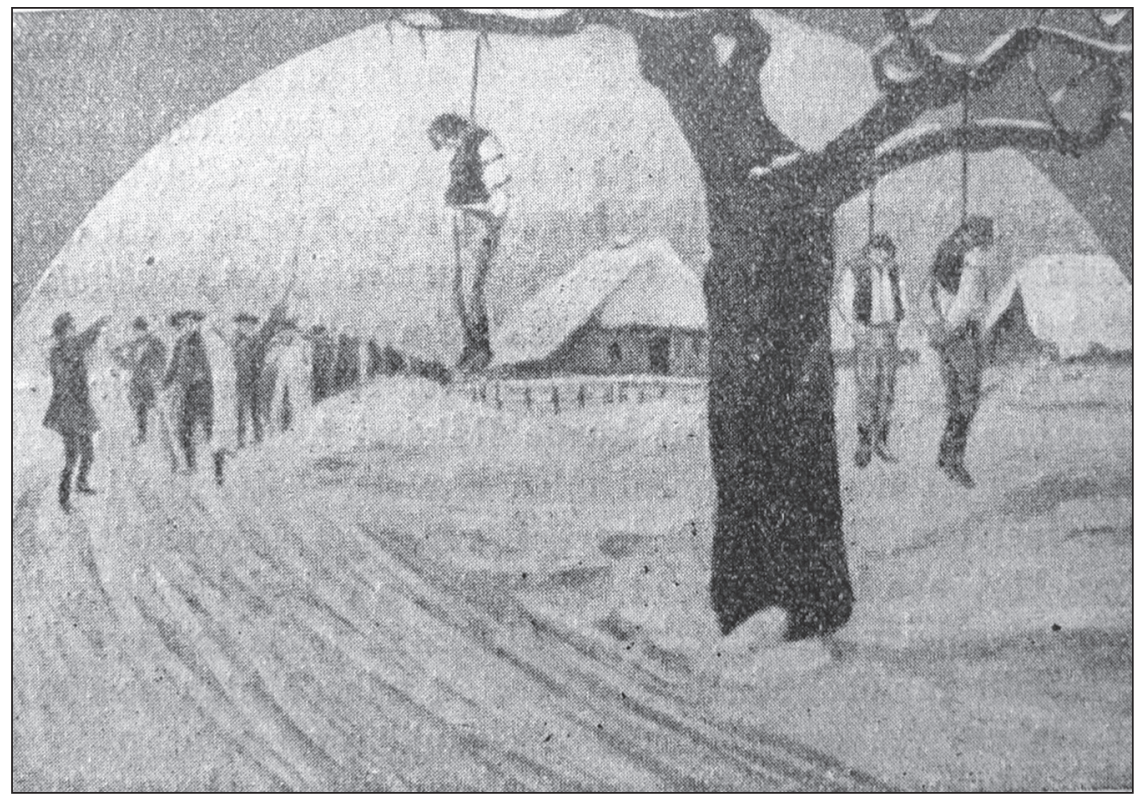

Figure 5 From the work of Pechány, Adolf: Mit tanitanak a felvidéki iskolákban? [What do they teach in Slovak schools?]. N. p. 1929, p. 22. This is a picture from Albert Pražák's history textbook for year three students of secondary schools. Hungarian past was regarded as an attempt to exterminate Slovaks.

19 See Holec, "The Černová Tragedy," 9-26; Holec, "A Trianon-diskurzus," 31-45; modified Holec, “Trianonský diskurz," 131-50. 
especially the period of the Dual Monarchy became objects of sharp criticism due to the ethnic practice and social policy, as well as the aristocratism and elitism of the society at the time. The attitude towards the Slovak workers' movement before 1918 was rather ambivalent and Czecho-Slovak cooperation was stressed in this sphere as well.

It was not until the 1960s that problematizing of the monarchy was possible, thanks to political détente. The best manifestation of these changes was a big international conference that was held in Bratislava to mark the centenary of the AustroHungarian Compromise. This led to the production of a 1000-page conference proceedings, which has retained its scholarly value up to now. ${ }^{20}$

In the following decades, several major monographs in the field of the political and economic history of the Habsburg monarchy were written by historians of the then 'middle generation' (Július Mésároš, Ladislav Tajták, Pavel Hapák, Milan Podrimavský, Milan Krajčovič, and Dušan Kováč et al.). ${ }^{21}$

After 1989, a new generation of historians emerged. With regard to the "long" nineteenth-century history of the Habsburg monarchy, they strengthened research in social history, the history of previously unstudied social classes, the church, nobility, bourgeoisie, and environmental history, as well as the politics of memory (Eva Kowalská, Elena Mannová, Peter Macho, Daniela Kodajová, Dušan Škvarna, Peter Švorc, László Vörös, Peter Šoltés, Gabriela Dudeková Kováčová, Štefan Gaučík, Daniel Hupko, Ján Golian, Miroslav Michela, Jakub Drábik, Attila Simon, and József Demmel, a Hungarian historian based in Slovakia). They enthusiastically started collaborating internationally and took part in discussions and foreign publications. ${ }^{22}$

An interesting phenomenon is the relatively neutral attitude towards the last rulers and members of the Habsburg dynasty. Books with these topics are popular among readers, which is also a result of their being a taboo subject before the year 1989. Biographies of this character are also represented by a wide range of translated literature.

Nowadays, a completely new generation, unburdened by this conflicted past, has entered the field with fresh new topics (Jana Májeková, Blažena Križová, et al.).

20 Vantuch and Holotík, eds, Der österreichisch-ungarische Ausgleich 1867.

21 Vörös, "Rozpad Uhorska" and other articles in this book written by Slovak and Hungarian historians.

22 Mannová, “Clio na slovenský spôsob”; Haslinger, “Národné alebo nadnárodné dejiny?”; Švorc, "Slovenská historiografia”; Dudeková, "Sociálne dejiny”; Macho, "Poznámky k výskumu kolektívnych," Holec, "Hospodárske dejiny na Slovensku”; Holec, “'Krátke’ dejiny 'dlhého’ storočia." 


\section{The most recent historiographic revisitations of the Monarchy and the year 1918}

The centenary of the monarchy's dissolution has led to a plethora of exhibitions ${ }^{23}$ and cultural events, as well as academic and non-academic literature. In professional historiography, brand new topics and new interpretative approaches have been brought to the table. Thanks to these, our knowledge has shifted to new contexts.

In relation to constructing historical consciousness in interwar Czechoslovakia, the importance of the Beneš Memoranda cannot be overlooked. The memoranda not only tried to legitimize the creation of the state, but also, in the spirit of the latter (at times calculating), argumentation and the national mythology was created-as well as public holidays, narratives in history textbooks, historical stereotypes, etc. ${ }^{24}$ The calculating aspect was not a one-off feature, only used at the peace conference, but it literally institutionalized the basic principles of official historical memory. In addition, it provided the new state with a certain political character and tasks: this was its political and historical-philosophical role.

The most recent Czech work in the field of the construction of historical memory focuses on the creation of public holidays in Czechoslovakia. ${ }^{25}$ The Slovak historian Miroslav Michela focused on Hungarian traditions and public holidays (15 March and 20 August), which were recoded and given new meaning after 1918. Despite the restrictions and sanctions imposed by the Czechoslovak government, the Hungarian minority preserved these traditions and public holidays. The Hungarians had a strong national and cultural awareness. After the dissolution of Austria-Hungary, it was as if they had "inherited" the role of the successors of the former Hungarian regime. For them, the monarchy's demise was a national tragedy. Both the chosen public holidays, as well as other local festivities and celebrations, promoted Hungarians' sense of national identity. Despite borders, this created an image of a unified Hungarian society brought together by historical misfortune.

Of the numerous Czech volumes dealing with the year 1918 and the history of Czechoslovakia, we will mention the most impressive one (over 1000 pages long). This was the result of collaboration between many foreign and Slovak (Jakub Drábik, Ludovít Hallon, Roman Holec, Rudolf Chmel, Dušan Kováč, Jakub Štofaník) historians. Here, too, entirely new topics have been identified thanks to completely new approaches to most of the problem areas. ${ }^{26}$ While the above-mentioned work commences with 1918 and continues up to the interwar period, a classic monograph

23 E.g. Česko-slovenská výstava; Besedič et al., Trianon. Zrod novej hranice.

24 See Krekovič, Mannová and Krekovičová, eds, Mýty naše slovenské; Findor, Začiatky národných dejín, but also Ducháček, Václav Chaloupecký.

25 Hájková et al., Sláva republice!

26 Hájková and Horák, eds, Republika československá 1918-1939. 
by Jan Rychlík, an expert in the field of Slovak studies, covers the period from the outbreak of World War I until the foundation of the republic. ${ }^{27}$ Of Slovak works, we can mention the latest book on Trianon, which completes and draws on earlier work by Miroslav Michela. ${ }^{28}$

In recent years, Slovak historiography has also managed to produce several significant pieces of work concerned with historical memory in relation to the final years of the monarchy. ${ }^{29}$ Most recently, a collective monograph dealing with the role of 1918 in Central European historical memory has been published in cooperation with Hungarian (László Szarka), Czech, and Polish historians. A similar project was separately carried out by Czech historians. ${ }^{30}$ Another work about one of the "founders" of Czechoslovakia, Milan Rastislav Štefánik, has also gained critical recognition thanks to its complexity and new approaches. It explores Štefánik as the symbol who has captured the imaginations of Czechoslovak historians and nurtured various political interpretations for decades. Among these, Peter Macho's innovative work stands out. It offers an insight into the phenomenon of a national hero, his posthumous cult, as well as his symbolic presence in public spaces, and the crucial contextual symbolism and related festivities. ${ }^{31}$ Štefánik has also been the subject of other approaches and of an impressive, unconventional modern biography that pieces together individual fragments of his life and constructs his persona around them. ${ }^{32}$ Moreover, the publication of numerous memoirs penned by ordinary Czech and Slovak soldiers has enhanced the historical memory of World War I even more. They recount time spent at the front, experiences as prisoners of war, and the new conditions that awaited them upon their return home.

Even in such an exact domain as the state economy, several links connecting the monarchy and the republic can be identified and thus considered its legacy. Some are of practical political and economic significance (budgeting); others are related to the mental state of post-World War I society and of inertia regarding certain stereotypes, but they, too, were directed towards economic practice.

A completely new topic has been introduced by Antonie Doležalová. ${ }^{33}$ When analyzing state budget planning after 1918, a strong tendency to copy the Austrian model can be observed. The Czechoslovak practice of creating state budgets was a continuation of the Austrian predecessor's modus operandi. The state budget took the

\footnotetext{
27 Rychlík, 1918. Rozpad Rakousko-Uherska.

28 Michela, Pod heslom integrity; Holec, Trianon. Triumf a katastrofa.

29 Michela and Vörös, eds, Rozpad Uhorska a trianonská mierová zmluva.

30 Letz and Makyna, eds, Rok 1918 v historickej pamäti Slovenska; Hálek and Moskovič, Fenomén Maffie.

31 Macho, Milan Rastislav Štefánik.

32 Kšiňan, Milan Rastislav Štefánik. See also Holec, Hlinka. Otec národa?

33 Doležalová, Rašín, Engliš a ti druzí.
} 
form of a constitutional law; however, it lacked sanctions associated with non-compliance with the budget rules. Other procedures such as dealing with a deficit, tax increases, etc., also copied Austrian economic approaches. The philosophical background that fostered a prominent role for the state and economic interventionism can be found in the World War I years. The role of the insatiable state bureaucracy consistently continued to grow. Before World War I, the state redistributed around 15 percent of GDP; however, after World War I, it was at least 25 percent. By the end of the 1930s, annually, national debt represented 46 percent of GDP, mainly because of the expansion of the state sector. Gradually, however, steps were taken to create distance from the Austro-Hungarian practice: this included the separate budgeting of investments or state enterprises, transfers of chapters, changes resulting from the different accounting of individual budget items, etc. Compared to other countries, the scope of the redistributive processes was extremely wide, and similarly, social expenditure was also extremely high. Despite this, compared to other successor states, Czechoslovakia fared exceptionally well. Inflationary pressure in Romania, Poland, the Kingdom of Serbians, Croatians, and Slovenians (not to mention in the defeated states such as Austria and Hungary) was considerably greater. It led to budgetary chaos, the accumulation of national debt, and the collapse of foreign trade.

It is intriguing to note the legacy of the monarchy in the economic sphere. It was the decisive role of the state concerning organizational, distributive, and decision-making matters that became prevailing. In the critical years of war, the state took responsibility for everything. This is why there was a strong tendency of the state to assume responsibility for everything after the war, as well as to place all decision-making power in the state's hands.

The Czechoslovak state behaved in quite the opposite way. The steadfast enforcement of economic liberalism rejected all conscious interference in economic development. Market and entrepreneurial mechanisms were left to run their course, and it was just the national framework of rules that was controlled. Understandably, such an approach discriminated against the Slovak economy due to the prevalence of enterprises that were not only financially undersized but also burdened with higher production costs. The latter were a significant threat to their existence; therefore, it is hardly surprising that in certain entrepreneurial circles and among economic elites, the spirit of nostalgia for the "good, old days" of Hungarian economic policy prevailed.

In this context, it was quickly forgotten that the highly regarded Hungarian so-called industrial acts $(1881,1890,1899,1907)$, which were considered an example of state-led industrialization, did not disadvantage individual regions, but a large proportion of their inhabitants. ${ }^{34}$

34 See Holec, "Die ungarische Wirtschafts- und Industriepolitik"; Pauliny, "Die Industriepolitik in Ungarn und Österreich”; Pázmándi, "Industrialisierung und Urbanisierung." 
Hungarian economic policy demonstrated growing tendencies towards protectionism, but internally, especially as regards legislation, a characteristic liberal approach was maintained. This allowed for the smooth formation of business entities and the business environment itself. From the outside, legislative measures aimed at supporting a domestic industrial sector seemed attractive. As a matter of fact, all decision-making processes and the effects of supportive measures were hampered by an ever-present framework of nationalism. The Hungarian government's policies that were meant to promote industry did not live up to expectations; nevertheless, the state had a key role in economic growth. The Hungarian government, hindered in its independent customs policy by the existing customs union, not only allowed the entry of foreign investment, but also used other ways of promoting industrial development, mainly subsidies-the most common mechanism for supporting industry. When inspecting the number of subsidies granted by the state to individual regions, we come to the surprising conclusion that Felvidék (approximately present-day Slovakia) had become the focal point of state support. If the textile and clothing industry was allocated the largest share of subsidies (57 percent), then Slovakia benefited from up to 40 percent of them. ${ }^{35}$ Zoltán Gál, who studied banks' capital strength and their business pre-World War I, reached corresponding conclusions. ${ }^{36}$

Slovakia inherited almost 19 percent of all industry in the predominantly agrarian Kingdom of Hungary. This figure corresponds to the number of people employed in industry, the number of industrial enterprises and other criteria. The Hungarian geographer Pál Beluszky attempted to determine the degree of "social modernization" in early twentieth century Hungary using twelve economic, social, cultural, and urbanization criteria. Four groups of regions were identified. Among them was the territory of the present-day Slovakia, which, along with Budapest, played a central part. This made clear how essential a position it played within the Hungarian state. ${ }^{37}$

The few economic elites in Slovakia departed the monarchy with concerns about the possibility that the unjust economic and political practices followed by the liberal Hungarian governments could repeat themselves in the newly founded Czechoslovak Republic. The threats were no longer assimilationist intentions and the ethnic discrimination experienced during their coexistence with Hungary, but mainly Czech economic strength.

35 Pázmándi, "Industrialisierung und Urbanisierung," 165. Also see MNL OL, Miniszterelnökség, K-28, 74. tétel, 30. cs., 19-1939-18768, A felsőmagyarországi gyáripar állami támogatása 1882-1914.

36 Gál, "A Felvidék városainak pénzintézeti funkciói."

37 Beluszky and Győri, Magyar városhálózat, 85-8. 
These worries were soon to be justified by further development in the republic. Czechoslovakia's heterogeneity (i.e., diverse levels of economic development) proved to be a drawback. Slovakia, the most developed region in Hungary (second to the Budapest agglomeration), delivered only 8 percent of the entire economic potential. It was only in the mid-thirties that Slovakia reached pre-war production levels. ${ }^{38}$ This was a source of politically motivated observations about how Slovaks had prospered within Hungary, and what pitfalls and dangers they were exposed to in Czechoslovakia. These were designed to blackmail Czechs by depicting an alternative to the Czech economic (and ultimately, political) practice.

Interpretations of the monarchy and the year 1918 in Slovak historiography are now devoid of any ideological burden, as well as of political and national instrumentalization. The crucial thing is not to put emphasis on who the agents of the 1918 coup were (domestic or exiled elites, foreign armies, the Entante, the working class etc.), or to cultivate pro-Entante or anti-Hungarian attitudes, as can be observed in some recent marginal and so-called nationally oriented texts. ${ }^{39}$ The Habsburg Monarchy in its last 50 years is a historical era that is an integral part of Slovak history. It should not be glorified or ignored, but neither should it be erased from the national narrative of the nineteenth and twentieth century.

\section{Sources}

Magyar Nemzeti Levéltár Országos Levéltára [National Archives of Hungary] (MNL OL) Miniszterelnökség, K-28 [Office of the Prime Minister].

Bandolová, Margita, et al., eds. Od Uhorského královstva k Československej republike. Dokumenty $z$ fondov slovenských regionálnych archivov $k$ udalostiam $v$ rokoch 1918-1919 [From the Kingdom of Hungary to the Czechoslovak Republic. Documents Relating to 1918-1919 from the Fonds of the Slovak Regional Archives]. Bratislava-Košice: MV SR, ŠA Bratislava, ŠA Košice, 2018.

Raschhofer, Hermann, ed. Die tschechoslowakischen Denkschriften für die Friedenskonferenz von Paris 1919/1920. Beiträge zum ausländischen öffentlichen Recht und Völkerrecht 24. Berlin: C. Heymanns, 1937.

38 See Holec, "Ekonomické aspekty"; Holec, "K problémom česko-slovenskej kapitálovej spolupráce”; Holec, "Die Slowaken zwischen Monarchie und Republik"; Holec, Štát s dvoma tvárami.

39 Typical of the national point of view are books and articles written by Slovak historian Marián Hronský. F. e. Hronský, The Struggle for Slovakia; Hronský, Mikulášska rezolúcia. 


\section{Literature}

Bartal, Michal, Jana Kafúnová, Marek Púčik and Martina Škutová, eds. Začleňovanie Slovenska do Československej republiky (s dôrazom na formovanie štátnych orgánov) [The Integration of Slovakia into the Czechoslovak Republic (with a Focus on the Formation of State Authorities)]. Bratislava: Ministerstvo vnútra Slovenskej republiky - Slovenský národný archív, 2018.

Belej, Milan, Peter Keresteš, and Miroslav Palárik, eds. Mílniky 20. storočia v regióne Nitrianskeho kraja [Milestones of the $20^{\text {th }}$ Century in the Region of Nitra]. Nitra: Ministerstvo vnútra Slovenskej republiky, 2018.

Beluszky, Pál and Róbert Győri. Magyar városhálózat a 20. század elején [Hungarian Urban Network at the Beginning of the $20^{\text {th }}$ Century]. Budapest-Pécs: Dialóg Campus, 2005.

Besedič, Martin, Dominika Čechová, Juraj Hrica, and Lenka Lubušká. Trianon. Zrod novej hranice. The New Border Creation. Bratislava: SNM, 2021.

Česko-slovenská výstava. Slovensko-česká výstava. [Czecho-Slovak Exhibition. SlovakCzech Exhibition]. Prague-Bratislava: SNM, NM, 2018.

Ducháček, Milan. Václav Chaloupecký. Hledání československých dějin. [Václav Chaloupecký. Seeking Czechoslovak History]. Prague: Karolinum, 2014.

Dudeková Kováčová, Gabriela. Človek vo vojne. Stratégie prežitia a sociálne dôsledky prvej svetovej vojny na Slovensku [The Man in the War. Survival Strategies and Social Consequences of World War I in Slovakia]. Bratislava: Veda, 2019.

Dudeková, Gabriela. "Sociálne dejiny 19. a 20. storočia na Slovensku - bilancia a nové impulzy" $\left[19^{\text {th }}\right.$ and $20^{\text {th }}$ Century Social History in Slovakia - An Overview and New Impulses]. Historický časopis 52, no. 2 (2004): 331-46.

Dudeková Kováčová, Gabriela. "Filantrop a sociálny politik, alebo čudák a rojko? Georg von Schulpe a jeho "pamätové stopy" [A Philanthropist and Social Reformer, or an Eccentric Utopist? Georg von Schulpe and his 'Memory Traces']. In V supermarkete dejín. Podoby moderných dejín a spoločnosti v stredoeurópskom priestore. Pocta Elene Mannovej [In the Supermarket of History. The Pattern of Modern History and Society in the Central European Region. In Honour of Elena Mannová], edited by Dudeková Kováčová, Gabriela, and Daniela Kodajová, 245-75. Bratislava: Veda, Historického ústavu Slovenskej akadémie vied, 2021.

Doležalová, Antonie. Rašín, Engliš a ti druzí [Rašín, Engliš and the Others]. Prague: Oeconomica, 2007.

Findor, Andrej. Začiatky národných dejín [The Beginnings of National History]. Bratislava: Kalligram, 2011.

Furmaník, Martin. Spiš a vznik Československej republiky [The Region of Spiš and the Creation of the Czechoslovak Republic]. Spišská Nová Ves: Múzeum Spiša v Spišskej Novej Vsi, 2018. 
Gál, Zoltán. "A Felvidék városainak pénzintézeti funkciói a századfordulón” [The Roles of Banks in Felvidék at the Turn of the Century]. In Felvidék történeti földrajza [The Historical Geography of the Felvidék], edited by Sándor Frisnyák, 455-74. Nyíregyháza: MTA Szabolcs-Szatmár-Bereg M. Tud. Test., 1998.

Gaučík, Štefan. Podnikv osídlach štátu. Podnikatelské elity na príklade Rimamuránskošalgótarjánskej železiarskej spoločnosti [The Enterprise in State Settlements. The Case of the Business Elites of the Rimamurány-Salgótarján Iron Works Corporation]. Bratislava: Veda, Historického ústavu Slovenskej akadémie vied, 2020.

Hájková, Dagmar and Horák, Pavel, eds. Republika československá 1918-1939 [The Czechoslovak Republic 1918-1939]. Prague: Lidové noviny, 2018.

Hájková, Dagmar, Pavel Horák, Vojtěch Kessler, and Miroslav Michela, eds. Sláva republice! Oficiální svátky a oslavy v meziválečném Československu [All Hail the Republic! Official Public Holidays and Festivities in Interwar Czechoslovakia]. Prague: Masarykův ústav a Archiv AV ČR, 2018.

Haslinger, Peter. "Národné alebo nadnárodné dejiny? Historiografia o Slovensku v európskom kontexte" [National or Supranational History? The Historiography on Slovakia in the European Context]. Historický ćasopis 52, no. 2 (2004): 269-80.

Hofman, Petr. "Causa Rudolf Kalhous" [The Rudolf Kalhous Case]. In Český lev a rakousky orel $v$ 19. století [The Czech Lion and the Austrian Eagle in the $19^{\text {th }}$ Century], edited by Zdeněk Hojda, and Roman Prahl, 190-96. Prague: KLP, 1996.

Holec, Roman. Dinamitos történelem. A pozsonyi Dynamit Nobel vegyipari konszern a közép-európai történelem keresztútján 1873-1945 [Dynamite Histories. The Bratislava Chemical Concern Dynamit Nobel at the Crossroads of Central European History (1873-1945)]. Bratislava: Kalligram, 2009.

Holec, Roman. Dejiny plné dynamitu. Bratislavský chemický koncern Dynamit Nobel na križovatkách novodobých dejín (1873-1960) [History Laden with Dynamite. The Bratislava Chemical Concern Dynamit Nobel at the Crossroads of Central European History (1873-1960)]. Bratislava: Kalligram, 2011.

Holec, Roman. "Ekonomické aspekty vzniku ČSR - ilúzie a realita" [The Economic Aspects of the Creation of the CzechoslovakRepublic - Illusion and Reality]. In Česko-slovenské vztahy. Slovensko-české vztahy [Czecho-Slovak Relations. Slovak-Czech Relations], 37-47. Liberec: TU Liberec, 1998.

Holec, Roman. "K problémom česko-slovenskej kapitálovej spolupráce do roku 1918" [On Czecho-Slovak Capital Cooperation up to 1918]. In Ludia - peniaze - banky [People - Money - Banks], 243-59. Bratislava: Národná banka Slovenska, AEP, 2003.

Holec, Roman. "DieSlowaken zwischen Monarchie und Republik. Wirtschaftsaspekte der Monarchieauflösung aus slowakischer Sicht." In Auflösung historischer Konflikte im Donauraum. Festschrift für Ferenc Glatz zum 70. Geburtstag, edited by Arnold Suppan, 593-610. Budapest: Akadémiai, 2011. 
Holec, Roman. Štát s dvoma tvárami (K hospodárskemu vývoju monarchie, Uhorska a Slovenska 1848-1867) [A Two-Faced State (On the Economic Development of the Monarchy, Hungary and Slovakia 1848-1867)]. Bratislava: HÚ SAV, Prodama, 2014.

Holec, Roman. "The Černová Tragedy and the Origin of Czechoslovakia in the Changes of Historical Memory." In Slovak Contributions to $19^{\text {th }}$ International Congress of Historical Sciences, edited by Dušan Kováč, 9-26. Bratislava: Veda, 2000.

Holec, Roman. "Hospodárske dejiny na Slovensku - stav a problémy výskumu" [The Economic History in Slovakia - the Current State and Research Problems]. Česko-slovenská historická ročenka 11 (2006): 41-58.

Holec, Roman. "Krátke' dejiny 'lhého' storočia" [Short History of the 'Long' Century]. Historický časopis 55, no. 1 (2007): 75-95.

Holec, Roman. Hlinka. Otec národa? [Hlinka. The Father of the Nation?]. Bratislava: PT Marenčin, 2019.

Holec, Roman. Trianon. Triumf a tragédia. [Trianon. A Triumph and Tragedy]. Bratislava: PT Marenčin, 2020.

Holec, Roman. "Die ungarische Wirtschafts- und Industriepolitik bis 1914 aus slowakischer Sicht." In Ausgebeutet oder alimentiert? Regionale Wirtschaftspolitik und nationale Minderheiten in Ostmitteleuropa (1867-1939), edited by Uwe Müller, 119-40. Frankfurter Studien zur Wirtschafts- und Sozialgeschichte Ostmitteleuropas 13. Berlin: Berliner Wissenschafts-Verlag, 2006.

Holec, Roman. "A Trianon-diskurzus a szlovák szépirodalomban" [The Trianon Discourse in Slovak Fiction]. Limes 23, no. 4 (2010): 31-45.

Holec, Roman. "Trianonský diskurz v slovenskej beletrii" [The Trianon Discourse in Slovak Fiction]. In Rozpad Uhorska a Trianonská mierová zmluva. K politikám pamäti na Slovensku a v Madarsku [The Dissolution of Hungary and the Treaty of Trianon. On Politics of Memory in Slovakia and Hungary], edited by Miroslav Michela and László Vörös, 131-50. Bratislava: HÚ SAV, 2013.

Hronský, Marián. The Struggle for Slovakia and the Treaty of Trianon. Bratislava: Veda, 2001.

Hronský, Marián. Mikulášska rezolúcia 1. mája 1918. [The Resolution of Liptovský Sv. Mikuláš from the $1^{\text {st }}$ May, 1918]. Bratislava: Veda, 2008.

Jarinkovič, Martin, Vojtech Kárpáty, and Erik Dulovič, eds. Košice 1918-1938. Zrod metropoly východného Slovenska [Košice 1918-1938. The Rise of the Metropolis of Eastern Slovakia]. Košice: MV SR, ŠA Košice, Východoslovenské múzeum, 2018.

Kerényi, Éva. “Gömör az 1919-es államfordulatok tükrében" [Gemer in the Light of the 1919 Coup]. Fórum. Társadalomtudományi Szemle 21, no. 2 (2019): 43-60. 
Klečacký, Martin. "Převzetí moci. Státní správa v počátcích Československé republiky 1918 - 1920 na př́kladu Čech" [The Power Take Over. The State Administration in Czechoslovak Republic's Early Years 1918-1920 - the Case of Bohemia]. Český časopis historický 116, no. 3 (2018): 693-732.

Kalhous, Rudolf. Budování armády [Building an Army]. Prague: Melantrich, 1936.

Kováč, Dušan. "Rok 1918 - kontinuita a diskontinuita v slovenskom politickom programe" [The year 1918 - the Continuity and Discontinuity in the Slovak National Program]. In Klúčové problémy moderných slovenských dejín [Key Questions of Modern Slovak History], edited by Valerián Bystrický, Dušan Kováč, and Jan Pešek, 136-54. Bratislava: Veda, 2012.

Kováč, Dušan, Eva Kowalská, and Peter Šoltés. Spoločnost' na Slovensku v dlhom 19. storoč́ [Society in Slovakia during the long 19 ${ }^{\text {th }}$ Century]. Bratislava: Veda, 2015.

Krekovič, Eduard, Elena Mannová, and Eva Krekovičová, eds. Mýty naše slovenské. [Our Slovak Myths]. Bratislava: AEP, 2005. (2nd ed. Bratislava: AEP, 2013)

Kšiňan, Michal. Milan Rastislav Štefánik. Muž, ktorýsa rozprával s hviezdami [Milan Rastislav Štefánik. The Man Who Spoke to the Stars]. Bratislava: Slovart, 2021. Letz, Róbert and Makyna, Pavol, eds. Rok 1918 v historickej pamäti Slovenska a strednej Európy [1918 in the Historical Memory of Slovakia and Central Europe]. Martin: Matica slovenská, 2020.

Luft, Robert. Parlamentarische Führungsgruppen und politische Strukturen in der tschechischen Gesellschaft. Tschechische Abgeordneten und Parteien des österreichischen Reichsrats 1907-1914. Vol. I-II. Munich: Oldenbourg, 2012.

Macho, Peter. Milan Rastislav Štefánik ako symbol [Milan Rastislav Štefánik as a Symbol]. Bratislava: Veda, 2019.

Macho, Peter. "Poznámky k výskumu kolektívnych identít v 19. a 20. storočí na Slovensku" [Some Notes on the Research of Collective Identities in the $19^{\text {th }}$ and $20^{\text {th }}$ Century]. Historický časopis 52, no. 2 (2004): 353-62.

Mannová, Elena. "Clio na slovenský spôsob. Problémy a nové prístupy historiografie na Slovensku po roku 1989" [The Slovak Version of Clio. New Problems and Approaches of the Slovak Historiography After 1989]. Historický ćasopis 52, no. 2 (2004): 239-46.

Mannová, Elena. Minulost ako supermarket? Spôsoby reprezentácie a aktualizácie dejín Slovenska [Past as a Supermarket? The Means of Representation and Adjustment of the History of Slovakia]. Bratislava: Veda, 2019.

Michela, Miroslav. Pod heslom integrity. Slovenská otázka v politike Mad'arska 19181921. [In the Name of Integrity. The Slovak Issue in Hungarian Policy, 19181921]. Bratislava: Kalligram, 2009.

Michela, Miroslav and László Vörös, eds. Rozpad Uhorska a trianonská mierová zmluva. K politikám pamäti na Slovensku a v Madarsku [The Dissolution of 
Hungary and the Treaty of Trianon. On Politics of Memory in Slovakia and Hungary]. Bratislava, HÚ SAV, 2013.

Palacký, František. Idea státu rakouského [The Idea of the Austrian State]. Olomouc: UP Olomouc, 2002.

Pauliny, Ákos. "Die Industriepolitik in Ungarn und Österreich und das Problem der ökonomischen Integration (1880-1914).” Zeitschrift für Wirtschafts- und Sozialwissenschaften 97, no. 2 (1977): 131-66.

Pázmándi, Susanne. "Industrialisierung und Urbanisierung und ihre Auswirkungen auf Deutsche und Magyaren in Oberungarn/Slowakei 1900-1938”. In Aspekte ethnischer Identität, edited by Edgar Hösch and Gerhard Seewann, 161-231. Munich: Oldenbourg, 1991.

Pehr, Michal. "Deset let existence meziválečného Československa. Oslavy 28. října 1928" [Ten Years of Interwar Czechoslovakia. The Celebrations of $28^{\text {th }}$ October in 1928]. In Rok 1918 v historickej pamäti Slovenska a strednej Európy [1918 in the Historical Memory of Slovakia and Central Europe], edited by Róbert Letz and Pavol Makyna, 189-208. Martin: Matica slovenská, 2020.

Rapant, Daniel. K počiatkom mad’arizácie [On the Onset of Magyarization]. Vol. I-II. Bratislava: FF UK, 1927-1931.

Rapant, Daniel. Ilegálna mad’arizácia 1790-1840 [Illegal Magyarization 1790-1840]. Martin: Matica slovenská, 1947.

Rychlík, Jan. 1918. Rozpad Rakousko-Uherska a vznik Československa [1918. The Dissolution of Austria-Hungary and the Creation of Czechoslovakia]. Prague: Vyšehrad, 2018.

Simon, Attila. "Tri obsadenia Košíc. Paralely a poučenia” [The Three Occupations of Košice. Parallels and Lessons Learned]. Fórum spoločenskovedná revue 21 (2019): 145-64.

Simon, Attila. Az első év kisebbségben. Az 1918/1919-es impériumváltás a mai DélSzlovákia térségében [Being a Minority, Year One. The 1918/19 Coup in Today's Southern Slovakia]. Šamorín: Fórum inštitút, 2021.

Simon, Attila. “Az 1918-19-es államfordulat első hetei Losoncon, Rimaszombatban és Rozsnyón" [The First Weeks of the 1918/19 Coup in the town of Lučenec, Rimavská Sobota and Rožňava]. Fórum. Társadalomtudományi Szemle 23, no. 2 (2021): 17-31.

Svetoň, Michal. Slováci v Mad’arsku [Slovaks in Hungary]. Bratislava: Spoločnost̉ pre zahraničných Slovákov, 1942. (German translation in 1943.)

Svetoň, Michal. Obyvatel'stvo Slovenska za kapitalizmu. [The Population of Slovakia in the Era of Capitalism]. Bratislava: SVPL, 1958.

Szeghy-Gayer, Veronika. "Meštanostovia na rázcestí. Stratégie, rozhodnutia a adaptácie najvyšších predstavitelov miest na nové politické pomery po roku 1918” 
[Mayors at the Crossroads. Strategies, Decisions and Adaptations of the Highest Town Officials Regarding the New Political Situation After 1918]. In Elity a kontraelity na Slovensku v 19. a 20. storočí. Kontinuity a diskontinuity $\left[19^{\text {th }}\right.$ and $20^{\text {th }}$ Century Elites and Counter-elites in Slovakia. Continuities and Discontinuities], edited by Adam Hudek and Peter Šoltés, 346-47. Bratislava: Veda, HÚ SAV, 2019.

Szeghy-Gayer, Veronika. Felvidékböl Szlovenszkó. Magyar értelmiségi útkeresések Eperjesen és Kassán a két világháború között [Felvidék into Slovakia. Magyar Intelligentsia Finding Their Place in Prešov and Košice Between the Two World Wars]. Bratislava: Kalligram, 2016.

Szeghy-Gayer, Veronika. "Államfordulat és az újra strukturálódó helyi elit Bártfán (1918-1919)" [The Coup and the Newly Formed Local Elites in the Town of Bardejov (1918 - 1919)]. Századok 152, no. 6 (2018): 1215-36.

Švorc, Peter. "Slovenská historiografia a regionálne dejiny 19. a 20. storočia. Slovensko ako regionálny prvok v historickom výskume” [The Slovak Historiography and Regional History of the $19^{\text {th }}$ and $20^{\text {th }}$ Century as a Regional Element in the Historical Research]. Historický časopis 52, no. 2 (2004): 295-308.

Ther, Philipp. "Druhý život habsburské monarchie v Československu. Poznámky ke kontinuitám po převratu 1918” [Habsburg Monarchy's Second Life in Czechoslovakia. Some Notes on Post-1918 Coup Continuities]. Střed 10, no. 1 (2018): 121-30.

Tokárová, Lucia and Richard Pavlovič, eds. Na ceste $k$ slovenskej štátnosti [On the Road to Slovak Statehood]. Bratislava: MV SR, 2018.

Urbanitsch, Peter. "Pluralist Myth and Nationalist Realities: The Dynastic Myth of the Habsburg Monarchy - a Futile Exercise in the Creation of Identity?" Austrian History Yearbook 35 (2004): 101-41. doi.org/10.1017/S0067237800020968

Vantuch, Anton and Ludovít Holotík, eds. Der österreichisch-ungarische Ausgleich 1867. Bratislava: SAV, 1971.

Vörös, László. “Rozpad Uhorska, vznik Československa a Trianon. Reprezentácie udalostí rokov 1918-1920 v mad’arskej a slovenskej historiografii” [The Disintegration of Hungarian Kingdom, the Formation of Czechoslovakia and Trianon. The Representations of the Events between 1918 and 1920 in Hungarian and Slovak Historiography]. In Rozpad Uhorska a trianonská mierová zmluva. K politikám pamäti na Slovensku a v Madarsku [The Dissolution of Hungary and the Treaty of Trianon. On Politics of Memory in Slovakia and Hungary], edited by Michela, Miroslav and László Vörös, 21-64. Bratislava, HÚ SAV, 2013.

Vörös, László. "Slovenský Wallenrod, národný renegát alebo úprimný vlastenec? Boj o 'pravdivý obraz' Samuela Czambela” [A Slovak Wallenrod, a National Renegade, or a Sincere Patriot? The Battle for a "True Image" of Samuel Czambel]. In $V$ supermarkete dejín. Podoby moderných dejín a spoločnosti $v$ 
stredoeurópskom priestore. Pocta Elene Mannovej. [In the Supermarket of History. The pattern of Modern History and Society in the Central European Region. In Honour of Elena Mannová], edited by Dudeková Kováčová, Gabriela, and Daniela Kodajová, 173-203. Bratislava: Veda, HÚ SAV, 2021.

(c) 2021 The Author(s).

(c) (i) (3) This is an open-access article distributed under the terms of the Creative Commons Attribution-Non Commercial 4.0 International Licence (CC BY-NC 4.0). 